\title{
Hubungan Sanitasi Dasar dengan Kejadian Diare pada Balita Di Wilayah Kerja Puskesmas Pembina Kota Palembang
}

\author{
Apriani Endawati ${ }^{1,2^{*}}$, Rico Januar Sitorus ${ }^{3}$, Heru Listiono ${ }^{4}$ \\ ${ }_{1,3,4}$ Universitas Kader Bangsa, Jln HM Ryacudu No 887 Ulu Palembang Sumatera Selatan \\ ${ }^{2}$ Dinas Lingkungan Hidup, Jl.Sukarela No.129.A, Sukarame Kota Palembang Sumatera Selatan \\ *Correspondence email: endawatia@gmail.com
}

\begin{abstract}
Abstrak. Diare merupakan penyebab kematian nomor satu pada bayi $31.4 \%$, balita $25.2 \%$, dan ke empat pada semuagolongan 13.2\%. Sumatera Selatan tepatnya Seberang Ulu II merupakan kecamatan memiliki angka tertinggi penyakit diare salah satunya di Puskesmas Pembina Kota Palembang 979 kasus. Tujuan penelitian ini untuk mengetahui analisis hubungan sanitasi dasar (kepemilikan jamban sehat, kepemilikan tempat pembuangan sampah, dan saluran pembungan air limbah) dengan kejadian diare pada balita. Penelitian ini mengguakan disain studi Cross Sectional dengan sampel yakni ibu yang memiliki balita usia 0-59 bulan yang berjumlah 52 responden. Pengambilan sampel dilakukan dengan menggunakan acidental sampling. Analisa mengunakan uji chi square. Hasil Penelitian menunjukkan bahwa ada hubungan yang signifikan kepemilikan jamban keluarga ( $\rho$ value 0.004 ; OR 7; 95\% Cl 2.012-24.358), kepemilikan tempat sampah ( $\rho$ value 0.000;OR 13; 95\% Cl 3,005-56,236), saluran pembuangan air limbah ( $\rho$ value 0.000 ; OR 15,75; 95\% Cl 3,601- 68,884) dengan kejadian diare pada balita. Kesimpulan distribusi kejadian diare $57.7 \%$ serta dari semua variabel terdapat hubungan yang signifikan dengan kejadian diare pada balita. Peneliti menyarankan pembuatan jamban, pembuatan kotak sampah tertutup dan pembuatan saluran pembuangan air limbah serta pengoptimalan program sosialisasi kesehatan lingkungan yakni pencegahan dan penanggulangan terhadap penyakit.
\end{abstract}

Kata kunci: Balita; Diare; Sanitasi Dasar

Abstract. Diarrhea was the number one case of death in baby $31.4 \%$, childhood $25 \%$ and The fourth in all age groups $13.2 \%$. South Sumatera precisely in Seberang Ulu II is a sub district that has highest rate of diarrhea disease one of the located in the working of Pembina health center were have that 979 cases. The purpose of this study was to association basic of sanitation (toilet quality, lay-stall and waste water disposal) related the incidence of diarrhea on childhood. This Research use propositional stratified accidental sampling (cross sectional) study design. The sample was mother that has children under five years old (0-59 month) and their were 52 respondent. The data analysis that was done bivariate and univariate data. Bivariate analysis used Chi square test. The result showed that there was significant correlation between toilet quality ( $\rho$ value $0.004 ; \mathrm{OR} \mathrm{7;95 \%} \mathrm{Cl} 2.012$ 24.358), laystall ( $\rho$ value 0.000; OR 13; 95\% Cl 3,005-56,236) and waste water disposal ( $\rho$ value 0.000; OR 15,75; $95 \% \mathrm{Cl}$ 3,601-68,884) with diarrhea childhood. The conclusion that the distribution of the incidence of diarrhea was 15,75\% and from all variable there was significant correlation with diarrhea in childhood. We suggest making latrines/toilet, constructing a simple covered garbage dumps and repair or making waste water disposal and optimizing environmental health socialization programs, namely prevention and control of disease.

Keywords: Childhood; Diarrhea; Basic Sanitation

\section{PENDAHULUAN}

Kesehatan merupakan hal yang sering terabaikan dan kita akan merasakan betapa besar keberadaannya saat kita kehilangan nikmat kesehatan tersebut. Kesehatan memang bukan segala-galanya akan tetapi segala yang kita miliki tidak akan berarti apa-apa tanpa adanya kesehatan. Merujuk pada Sistem Kesehatan Nasional, maka pembangunan dan upaya tercapainya kemampuan untuk hidup sehat bagi setiap penduduk dalam mewujudkan derajat kesehatan masyarakat yang optimal merupakan salah satu unsur kesejahteraan umum dari tujuan nasional. Derajat Kesehatan dapat dicapai melalui upaya-upaya perbaikan sanitasi lingkungan, pengendalian dan pemberantasan penyakit menular, pendidikan kesehatan, pengorganisasian pelayanan atau perawatan kesehatan serta pengembangan unsur-unsur sosial untuk menjamin taraf kehidupan yang layak (Chandra, 2012).
Balita merupakan kelompok umur yang rawan gizi dan rawan penyakit, utamanya penyakit infeksi, salah satu penyakit infeksi pada balita adalah diare. Diare lebih dominan menyerang balita karena daya tahan tubuh balita yang masih lemah sehingga balita sangat rentan terhadap penyebaran virus penyebab diare. Diare merupakan salah satu penyebab angka kematian dan kesakitan tertinggi pada anak, terutama pada balita. Di dunia terdapat 6 juta balita yang meninggal tiap tahunnya karena penyakit diare dan sebagian kematian tersebut terjadi di negara berkembang termasuk Indonesia (Kementerian Kesehatan RI, 2012).

Sanitasi lingkungan sebagai bagian penting dari peningkatan derajat kesehatan yang mana pada hakekatnya sanitasi lingkungan adalah kondisi atau keadaan lingkungan yang optimum sehingga berpengaruh positif terhadap status kesehatan yang optimum pula. Sanitasi lingkungan mengutamakan pencegahan terhadap faktor lingkungan sedemikian rupa 
sehingga munculnya penyakit akan dapat dihindari. Usaha sanitasi dapat berarti pula suatu usaha untuk menurunkan jumlah bibit penyakit yang terdapat di lingkungan sehingga derajat kesehatan manusia terpelihara dengan sempurna. Menurut Riset Kesehatan Dasar, sanitasi dasar adalah salah satu hal yang paling penting dalam mencapai suatu derajat kesehatan dimana keberadaan sanitasi dasar mempengaruhi penyebaran suatu penyakit. Ruang lingkup sanitasi dasar rumah tangga meliputi ketersedian jamban, penyediaan air bersih, pengelolaan sampah dan saluran pembuangan air limbah. Sanitasi berhubungan dengan kesehatan lingkungan yang dapat mempengaruhi derajat kesehatan masyarakat. Dampak dari rendahnya tingkat cakupan sanitasi dapat menurunkan kualitas hidup masyarakat, tercemarnya sumber air minum bagi masyarakat, meningkatnya penyakit berbasis lingkungan seperti diare. Diare adalah gangguan buang air besar atau BAB ditandai dengan $\mathrm{BAB}$ lebih dari 3 kali sehari dengan konsistensi tinja cair, dapat disertai dengan darah atau lendir (Riskesdas, 2013).

Faktor-faktor penyebab timbulnya penyakit diare pada balita antara lain sanitasi dasar yaitu penyediaan air bersih, kepemilikan jamban keluarga, kepemilikan tempat pembuangan sampah dan saluran pembuangan air limbah (SPAL) dan keadaan sosial ekonomi (pengetahuam, umur, pendidikan, pendapatan dan pekerjaan). Selain itu juga kejadian diare, dipengaruhi oleh status gizi balita, kependudukan (kepadatan), pendidikan, dan perilaku masyarakat (Notoatmodjo, 2011)

Penyakit diare adalah penyakit yang sangat berkaitan erat dengan kondisi sanitasi dasar, dimana sanitasi dasar yang buruk berisiko menjadi penyebab penyakit diare. Pada Peraturan Pemerintah No. 66 Tahun 2014 Tentang Kesehatan Lingkung menjelaskan bahwa faktor lingkungan seperti kepemilikan jamban sehat terbukti untuk memutus mata rantai penularan penyakit salah satunya diare (Peraturan Pemerintah RI Nomor 66 Tahun 2014, n.d.).

Di negara berkembang termasuk Indonesia anakanak menderita diare lebih dari 12 kali per tahun dan hal ini yang menjadi penyebab kematian sebesar 15-34\% dari semua penyebab kematian (Kementerian Kesehatan RI, 2012).

Diare merupakan penyakit endemis di Indonesia dan juga merupakan penyakit potensial Kejadian Luar Biasa (KLB) yang sering disertai dengan kematian. Diperkirakan 1,8 juta orang meninggal karena penyakit diare setiap tahun, di mana lebih dari $80 \%$ kasus tersebut terjadi pada anak-anak dengan usia di bawah lima tahun (UNICEF, 2012). Kematian akibat diare paling banyak terjadi pada anak dengan tingkat malnutrisi dan kemiskinan yang tinggi (UNICEF, 2012).

Data dari Kementrian Kesehatan Republik Indonesia menunjukkan bahwa terdapat 30.775 kasus diare pada tahun 2013, dimana kasus diare tersebut menempati urutan ke-7 dari 10 besar penyakit lainnya, sedangkan kejadian diare pada Balita menempati urutan ke-2 dari 10 besar penyakit lainnya. Kasus diare merupakan penyebab kematian nomor satu pada bayi (31.4\%) dan balita (25.2\%), sedangkan pada golongan semua umur merupakan penyebab kematian yang ke empat (13.2\%) (Kementerian Kesehatan RI, 2013).

Diare di Indonesia merupakan penyakit endemis dan juga penyakit potensial kejadian luar biasa (KLB) yang sering disertai dengan kematian. Pada tahun 2015 terjadi 18 kali KLB diare dengan jumlah penderita 1.213 orang dan kematian 30 orang $(2,47 \%)$. Angka kematian saat KLB diare diharapkan $<1 \%$, namun berdasarkan rekapitulasi KLB diare dari tahun 2008-2015, di tahun 2008 angka kematian saat KLB masih cukup tinggi (>1\%) yaitu 2,94\%, kecuali pada tahun 2011 angka kematian saat KLB 0,40\%, sedangkan tahun 2015 angka kematian diare saat KLB bahkan meningkat menjadi 2,47\%. Angka kesakitan nasional hasil Survei Morbiditas Diare tahun 2012 yaitu sebesar 214/1.000 penduduk. Maka diperkirakan jumlah penderita diare di fasilitas kesehatan sebanyak 5.097.247 orang, sedangkan jumlah penderita diare yang dilaporkan ditangani di fasilitas kesehatan sebanyak 4.017.861 orang atau 74,33\% (Kementerian Kesehatan RI, 2011).

Berdasarkan laporan Riskesdas Tahun 2013, periode prevalens penyakit diare di Indonesia mencapai $3,5 \%$ dan paling banyak menyerang pada balita. Penyakit diare diestimasikan berhubungan dengan sarana air bersih dan ketersediaan fasilitas sanitasi dasar. Pada Laporan Pusat Data dan Informasi Profil Kesehatan Indonesia 2017 (Dinas Kesehatan Kota Palembang, 2017).

Dampak negatif penyakit diare pada bayi dan anak-anak antara lain adalah menghambat proses tumbuh kembang anak yang pada akhirnya dapat menurunkan kualitas hidup anak. Penyakit diare di masyarakat (Indonesia) lebih dikenal dengan istilah "Muntaber". Penyakit ini mempunyai konotasi yang mengerikan serta menimbulkan kecemasan dan kepanikan warga masyarakat karena bila tidak segera diobati, dalam waktu singkat ( \pm 48 jam) penderita akan meninggal (Notoatmodjo, 2011).

Angka kesakitan diare di Indonesia dari tahun ke tahun cenderung meningkat, pada tahun 2010 jumlah kasus diare sebanyak 10.980 penderita dengan jumlah kematian 277 (CFR 2,52\%). Secara keseluruhan diperkirakan angka kejadian diare pada balita berkisar antara 40 juta setahun dengan kematian sebanyak 200.000 sampai dengan 400.000 balita. Pada survei tahun 2013 yang dilakukan oleh Depkes RI melalui Ditjen P2MPL di 10 provinsi didapatkan hasil bahwa dari 18.000 rumah tangga yang disurvei diambil sampel sebanyak 13.440 balita, dan kejadian diare pada balita yaitu 1,3 episode kejadian diare pertahun (Soebagyo, 2008) 
Apriani Endawati, Rico Januar Sitorus dan Heru Listiono, Hubungan Sanitasi Dasar dengan Kejadian Diare pada Balita Di Wilayah Kerja Puskesmas Pembina Kota Palembang

Angka kejadian untuk kasus diare di Sumatera Selatan masih cukup tinggi yakni sebesar 223.209 kasus. Kasus ini mengalami penurunan dari tahun 2013- 2016 sebesar 26\%, namun pada tahun 2016-2017 terjadi peningkatan kasus diare yakni sebesar $10 \%$. Angka kejadian diare tertinggi di dataran rendah dan pinggiran Sungai Musi Kota Palembang berdasarkan wilayah kerja puskesmas terdapat di beberapa wilayah kerja yakni, Puskesmas Pembina, Puskesmas Nagaswidak, Puskesmas Makrayu, dan Puskesmas. Penyebabnya dapat dilihat dari hygiene dan sanitasi yang belum memenuhi syarat seperti air yang digunakan sebagai MCK maupun padatan hunian yang ditempati (Dinas Kesehatan Kota Palembang, 2017). Seperti halnya dengan kejadian diare yang terjadi di Kecamatan Seberang Ulu I, faktor risiko paling dominan yang berperan dalam kejadian diare pada balita adalah kebiasaan mencuci tangan dan sumber air yang digunakan (Italia et al., 2016)

Berdasarkan profil kesehatan Kota Palembang tahun 2019 penyakit diare termasuk diantara ke 10 (sepuluh) urutan penyakit terbesar dengan jumlah kasus 39.256 orang dengan persentase balita sekitar 54,1\%, Tahun 2018 jumlah penderita 43,842 kasus dengan persentase pada balita $54,99 \%$, sedangkan di Tahun 2019 jumlah penderita diare meningkat menjadi 47.365 dengan persentase balita 55,5 \% (Dinas Kesehatan Provinsi Sumatera Selatan. Subdin P2P Sum-Sel, 2019).

Wilayah Kerja Puskesmas Pembina Kota Palembang, dengan jumlah penduduk 37.830 jiwa, penderita diare, Tahun 2016 sebanyak 928, balita sebesar 442 (47,6 \%). Tahun 2017 adalah 979 kasus pada balita 508 ( 66,8 \%). Pada tahun 2018 adalah 979 kasus pada balita $508(51,9 \%)$

Penyakit diare tersebut bukan hanya terjadi ataupun menular pada orang dewasa, namun penyakit diare juga dapat terjangkit pada Balita. dilihat dari survei lingkungan dan hasil data yang di peroleh dari Puskesmas Pembina Kota Palembang bahwa banyak anak balita yang terjangkit diare yang di dasari oleh faktor-faktor di lingkungan sekitarnya

Sebagian masyarakat Kota Palembang bermukim di dataran rendah dan tepian Sungai Musi dimana permukiman penduduk tersebut cukup padat dan memiliki kondisi sanitasi yang memprihatinkan. Jarak antar bangunan sangat rapat, lorong - lorong yang sempit dan kondisi rumah yang terletak di atas aliran air sungai semakin membuat kawasan ini menjadi kumuh. Kondisi tersebut diakibatkan karena sebagian besar masyarakat melakukan kegiatan mandi cuci kakus di pinggir sungai, membuang sampah langsung ke rawarawa dan sungai, tidak memiliki jamban sehat, serta tidak mengelola limbah rumah tangga dengan benar (Pratama, 2013).

Kualitas perairan Sungai Musi tidak layak digunakan karena telah tercemar polutan dari industri dan feses yang ditunjukkan pada beberapa nilai dari parameter uji yang melebih batas ambang yang diperkenankan untuk perairan sungai (Windusari \& Sari, 2015).

Banyak faktor yang menyebabkan kejadian diare pada balita seperti penyediaan air bersih, kepemilikan jamban keluarga, kepemilikan tempat pembuangan sampah dan saluran pembuangan air limbah (SPAL) dan keadaan sosial ekonomi (pengetahuam, umur, pendidikan, pendapatan dan pekerjaan). Selain itu juga kejadian diare, dipengaruhi oleh status gizi balita, kependudukan (kepadatan), pendidikan, dan perilaku masyarakat (Notoatmodjo, 2011).

Tujuan penelitian ini untuk mengetahui analisis hubungan sanitasi dasar (kepemilikan jamban sehat, kepemilikan tempat pembuangan sampah, dan saluran pembungan air limbah) dengan kejadian diare pada balita.

\section{METODE}

Desain penelitian ini menggunakan Metode Survei Analitik dengan dengan pendekatan Cross Sectional, Desain ini digunakan sesuai dengan tujuan penelitian untuk melihat hubungan sesaat antara variabel independen dan variabel dependen dengan pengambilan data independen (kepemilikan jamban keluarga, kepemilikan tempat pembuangan sampah dan saluran pembuangan air limbah (SPAL)) dan dependen (kejadian diare pada balita) yang dikumpulkan dalam waktu yang bersamaanLokasi Penelitian di Wilayah Kerja Puskesmas Pembina Kota Palembang Tahun 2020. Populasi dalam penelitian adalah seluruh balita usia 0-59 bulan dengan respoden yaitu ibu balita/ keluarga tersebut yang berada di Wilayah Kerja Puskesmas Pembina Kota Palembang Tahun 2020, dengan jumlah populasi, sebanyak 52 kasus pada balita.

Sampel adalah ibu-ibu yang mempunyai balita usia 0-59 bulan yang berada di Wilayah Kerja Puskesmas Pembina Kota Palembang Tahun 2020.

Rancangan sampel adalah acidental sampling yaitu pengambilan sampel yg datang pada saat kejadian dari populasi yang telah diberi nomor urut atau anggota sampel diambil dari populasi. Menurut teori (Arikunto, 2009) apabila jumlah populasi $\leq 100$, maka seluruh populasi dijadikan sampel sedangkan bila jumlah populasi > 100, maka di ambil 10-20 \% dari total populasi. Jumlah sampel yang diteliti pada penelitian adalah sebanyak 52 orang sebagai responden.

Pengumpulan data dilakukan untuk memperoleh informasi yang bersumber dari data primer. Data primer diperoleh dengan cara mewanwancarai langsung melalui responden yang menjadi sampel penelitian. Data primer merupakan lembar kuesioner yang berisi pertanyaan tentang sanitasi dasar responden penelitian yang dibagikan kepada responden lalu dijawab guna mengetahui bagaimana gambaran sanitasi dasar yang dimiliki oleh responden penelitian,Setelah dijawab, 
Apriani Endawati, Rico Januar Sitorus dan Heru Listiono, Hubungan Sanitasi Dasar dengan Kejadian Diare pada Balita Di Wilayah Kerja Puskesmas Pembina Kota Palembang

kuisioner dikumpulkan oleh peneliti dan dilakukan pengolahan data.

Proses penyederhanaan data ke dalam bentuk yang lebih mudah dibaca dan diinterprestasikan dengan menggunakan perangkat komputer kemudian dilakukan analisis (Sabri, 2006) : Analisis univariat adalah analisis yang digunakan untuk mengetahui distribusi frekuensi dan persentase dari masing-masing variabel yang diteliti baik variabel dependen maupun Variabel independen dan Analisis Bivariat adalah analisis yang digunakan untuk mengetahui hubungan antara variabel dependen dan independen yang terjadi memang bermakna secara statistik. kemudian dianalisis dengan menggunakan uji Chi-square dengan tingkat kemaknaan nilai $\alpha \dot{\alpha}(0,05)$, dengan kriteria Uji yang bertujuan untuk melihat adanya hubungan kejadian diare pada balita di Wilayah Kerja Puskespas Pembina Kota Palembang. Dasar pengambilan hipotesis peneliti pada tingkat signifikasi (nilai $\rho$ ) yaitu :

1. Bila nilai $\rho$ value $\leq 0,05$, berarti ada hubungan yang bermakna (signifikan) antara variabel dependen dengan variabel independen.

2. Bila nilai $\rho$ value $>0,05$, berarti tidak ada hubungan yang bermakna (signifikan) antara variabel dependen dengan variabel independen.

\section{HASIL DAN PEMBAHASAN \\ Analisis Univariat}

Analisis ini dilakukan untuk memperoleh gambaran distribusi frekuensi dan presentase responden menurut semua variabel penelitian baik variabel dependen (kejadian diare pada Balita) maupun variabel independen (kepemilikan jamban keluarga, kepemilikan tempat pembuangan sampah dan SPAL) yang dikumpulkan dalam tabel 1 dan teks dibawah ini. (Tabel 1).

Tabel 1. Distribusi Frekuensi Variabel Independen dan Dependen

\begin{tabular}{|c|c|c|c|}
\hline No & Variabel Penelitian & Total & $\begin{array}{c}\text { Persentase } \\
(\%)\end{array}$ \\
\hline \multirow[t]{3}{*}{1} & Kepemilikan Jamban Keluarga & & \\
\hline & 1. Tidak Ada & 32 & 61,50 \\
\hline & 2. Ada & 20 & 38,50 \\
\hline \multirow[t]{3}{*}{2} & Kepemilikan Tempat Sampah & & \\
\hline & 1. Tidak Ada & 36 & 69,20 \\
\hline & 2. Ada & 16 & 30,80 \\
\hline \multirow[t]{4}{*}{3} & Kepemilikan Pembuangan Air & & \\
\hline & Limbah & 35 & 67,30 \\
\hline & 1. Tidak Ada & 17 & 32,70 \\
\hline & 2. Ada & & \\
\hline \multirow[t]{3}{*}{4} & Kejadian Diare Balita & & \\
\hline & 1. Diare & 48 & 49,0 \\
\hline & 2. Tidak Diare & 50 & 51,0 \\
\hline
\end{tabular}

Sumber data: hasil penelitian.

Dari tabel 1 diatas terlihat bahwa proporsi Kepemilikan jamban keluarga terbanyak yakni tidak ada 32 orang $(61,50 \%)$, Kepemilikan tempat sampah tidak ada 36 orang $(69,20 \%)$, Kepemilikan saluran pembuangan air limbah tidak ada 35 orang $(67,30 \%)$, Kejadian diare pada balita diare 30 orang $(42,30 \%)$.

\section{Analisis Bivariat}

Tabel 2. Hubungan Variabel Independen dengan Variabel Dependen

\begin{tabular}{|c|c|c|c|c|c|c|c|c|c|}
\hline \multirow{3}{*}{ No } & \multirow{3}{*}{ Variabel Independen } & \multicolumn{4}{|c|}{ Kejadian Diare } & \multirow{2}{*}{\multicolumn{2}{|c|}{ Total }} & \multirow{3}{*}{$\begin{array}{c}\text { Odd Ratio } \\
95 \% \text { CI }\end{array}$} & \multirow{3}{*}{$\rho$ value } \\
\hline & & \multicolumn{2}{|c|}{ Diare } & \multicolumn{2}{|c|}{ Tidak Diare } & & & & \\
\hline & & $\mathrm{n}$ & $\%$ & $\mathrm{n}$ & $\%$ & $\mathrm{~N}$ & $\%$ & & \\
\hline \multirow[t]{3}{*}{1} & Kepemilikan Jamban keluarga & & & & & & & & \multirow[b]{3}{*}{0,004} \\
\hline & Tidak Ada & 24 & 75 & 8 & 25 & 32 & 100 & 7 & \\
\hline & Ada & 6 & 30 & 14 & 70 & 20 & 100 & $(2,012-24,358)$ & \\
\hline \multirow[t]{3}{*}{2} & $\begin{array}{l}\text { Kepemilikan tempat pembuangan } \\
\text { sampah }\end{array}$ & & & & & & & & \\
\hline & Tidak Ada & 27 & 75 & 9 & 25 & 35 & 100 & 13 & \multirow{2}{*}{0,000} \\
\hline & Ada & 3 & 18,8 & 13 & 81,3 & 17 & 100 & $(3,005-56,236)$ & \\
\hline \multirow[t]{3}{*}{3} & Kepemilikan SPAL & & & & & & & & \multirow{3}{*}{0,000} \\
\hline & Tidak Ada & 27 & 77,1 & 8 & 22,9 & 35 & 100 & 15,75 & \\
\hline & Ada & 3 & 17,6 & 14 & 82,4 & 24 & 100 & $(3,601-68,884)$ & \\
\hline
\end{tabular}

Sumber data: hasil penelitian.

\section{Hubungan Kepemilikan Jamban Dengan Diare Balita} Dari tabel 2 diatas dapat dilihat Ditribusi kejadian diare balita dengan Kepemilikan jamban keluarga sejumlah bahwa dari 32 responden tidak memiliki jamban keluarga dan ada kejadian diare sebanyak 24 responden $(75,0 \%)$ lebih besar bila dibandingkan 20 responden yang memiliki jamban keluarga hanya 6 orang $(30,0 \%)$.

Hasil uji statistik dengan uji Chi-Square diperoleh hasil $\rho$ value $0,004<0,05$. Ini berarti secara statistik dapat disimpulkan ada hubungan yang signifikan antara Kepemilikian Jamban Keluarga dengan Kejadian Diare pada Balita di Wilayah Kerja Puskesmas Pembina Kota Paembang.

Dari hasil analisis nilai Odds Ration (OR) sebesar 7,000 , dengan demikian berarti responden yang tidak memiliki jamban keluarga berpeluang 7,000 kali terserang kejadian diare pada balita bila dibandingkan dengan responden yang memiliki jamban keluarga di Puskesmas Pembina Kota Palembang tahun 2020. 
Hasil Penelitian ini sejalan dengan hasil penelitian yang dilakukan oleh Meithyra Melviana S (Simatupang, 2014) tentang Hubungan Sanitasi Jamban Dan Air Bersih Dengan Kejadian Diare Pada Balita Di Kelurahan Terjun Kecamatan Medan Marelan Kota Medan Tahun 2014 diperoleh bahwa kondisi jamban yang memenuhi syarat jamban sehat di Kelurahan Terjun ada sebanyak 9 $(30 \%)$, sementara yang tidak memenuhi syarat jamban sehat sebanyak 21(70\%), sedangakan untuk penggunaan Jamban oleh balita dengan kategori selalu sebanyak 10 $(33,3 \%)$, sementara kategori kadang-kadang 20 (66,7\%).

Berdasarkan dari hasil data yang didapat, masih banyak masyarakat di wilayah kerja Puskesmas Pembina Kota Palembang kurang menyadari akan perlunya memiliki jamban keluarga yang bersih dan sehat sehingga mempermudah timbulnya kejadian diare pada balita.

Jamban adalah fasilitas pembuangan kotoran manusia yang terdiri dari tempat duduk/jongkok dengan leher angsa yang dilengkapi dengan tempat penampungan kotoran dan air untuk membersihkan (Sarudji, 2010).

Jamban Sehat Menurut (Notoatmodjo, 2007) adalah sebagai berikut tidak mengotori tanah disekelilingnya, tidak mengotori permukaan tanah sekitarnya, tidak mengotori air tanah disekitarnya, tidak terjangkau oleh serangga, tidak menimbulkan bau, mudah digunakan dan dipelihara, dan desainnya sederhana. Jamban merupakan suatu bangunan yang berfungsi mengumpulkan kotoran manusia yang tersimpan pada tempat tertentu sehingga tidak menjadi penyebab suatu penyakit atau mengotori permukaan bumi. Jamban sangat berguna bagi manusia dan merupakan bagian dari kehidupan manusia, karena jamban dapat mencegah berkembangnya berbagai penyakit saluran pencernaran yang disebabkan oleh kotoran manusia yang tidak dikelola dengan baik.

\section{Hubungan Kepemilikan Pembuangan Sampah Dengan Diare Balita}

Dari tabel 2 diatas dapat dilihat Ditribusi kejadian diare balita dengan Kepemilikan tempat pembuangan sampah sejumlah bahwa dari 35 responden tidak memiliki tempat sampah dan ada kejadian diare sebanyak 27 responden $(75,0 \%)$ lebih besar bila dibandingkan 17 responden yang memiliki tempat pembuangan sampah hanya 3 orang $(18,8 \%)$.

Hasil uji statistik dengan uji Chi-Square diperoleh hasil $\rho$ value $0,000<0,05$. Ini berarti secara statistik dapat disimpulkan ada hubungan yang signifikan antara Kepemilikan Tempat Pembuangan Sampah dengan Kejadian Diare pada Balita.

Dari hasil analisis nilai Odds Ration (OR) sebesar 13,00 dengan demikian berarti responden yang tidak memiliki tempat pembuangan sampah yang berkatagori sehat berpeluang 13,00 kali terserang kejadian diare pada balita bila dibandingkan dengan responden yang memiliki tempat pembuangan sampah di Wilayah Kerja Puskesmas Pembina Kota Palembang Tahun 2020.

Bahwa kondisi tempat sampah yang kurang baik serta membuang sampah disembarang tempat atau dibuang begitu saja baik itu sampah organik maupun sampah anorganik dapat menimbulkan pemandangan dan bau yang tidak sedap disekitar rumah mereka sedangkan kaleng atau ember bekas tersebut dapat menjadi tempat perindukkan nyamuk dan lalat sebagai vector penyebab penyakit.

Pengelolaan sampah mutlak diperlukan mengingat dampak buruknya bagi kesehatan dan lingkungan, sampah menjadi tempat berkembangbiaknya organisme penyebab dan pembawa penyakit seperti diare.

Pengelolaan sampah yang terjadi selama ini tidak memberikan dampak positif kepada lingkungan, dan kurangnya kebijakan dari pemerintahan. Pengelolaan Sampah seharusnya bisa dimanfaatkan kembali, sehingga dapat mengurangi tumpukan sampah serta memperoleh nilai ekonomi dari pengelolaan sampah

\section{Hubungan Kepemilikan Pembuangan Limbah Dengan Kejadian Diare Balita}

Dari tabel 2 diatas dapat dilihat distribusi kejadian Diare balita dengan Kepemilikan Saluran pembuangan air limbah sejumlah bahwa dari 35 responden tidak memiliki SPAL sejumlah 27 orang $(77,1 \%)$ lebih besar bila dibandingkan 24 responden memiliki SPAL hanya 3 orang $(17,6 \%)$.

Hasil uji statistik dengan uji Chi-Square mendapatkan hasil $\rho$ value $0,000<0,05$. Ini berarti ada hubungan yang signifikan antara Kepemilikan SPAL dengan kejadian Diare pada Balita di Wilayah Kerja Puskesmas Pembina Kota Palembang.

Dari hasil analisis nilai Odds Ration (OR) sebesar 15,75 dengan demikian berarti responden yang tidak memiliki SPAL berpeluang 15,75 kali terserang kejadian diare pada balita bila dibandingkan dengan responden yang memiliki SPAL di Puskesmas Pembina Kota Palembang Tahun 2020.

Penelitian (Desi Payana, 2009), menyatakan ada hubungan Saluran Pembuangan Air Limbah (SPAL) dengan kejadian diare pada balita di wilayah kerja Puskesmas 11 Ilir Palembang.Penggunaan saluran pembuangan air limbah oleh masyarakat di wilayah kerja puskesmas Pembina Kota Palembang masih banyak mengalirkannya ke selokan yang terbuka dan jarang dibersihkan, sehingga mempermudah terjadinya diare karena kurangnya kesadaran dalam kebersihan lingkungan sekitar.

Kepemilikan Saluran Pembuangan Air Limbah (SPAL) adalah adanya roil atau got yang dibuat sebelum menuju badan air Dalam penelitian ini kepemilikan jamban keluarga dibagi menjadi 2 (dua) kategori yaitu tidak ada, bila tidak mempunyai SPAL dan ada, bila mempunyai SPAL. 
Apriani Endawati, Rico Januar Sitorus dan Heru Listiono, Hubungan Sanitasi Dasar dengan Kejadian Diare pada Balita Di Wilayah Kerja Puskesmas Pembina Kota Palembang

Saluran pembuangana Air limbah yang sehat yaitu yang dapat mengalirkan air limbah dari sumbernya (dapur, kamar mandi) ke tempat penampungan air limbah dengan lancar tanpa mencemari lingkungan dan tidak dapat dijangkau serangga. rumah yang membuang air limbah di atas tanah terbuka tanpa adanya saluran pembuangan limbah akan membuat kondisi lingkungan menjadi kotor, becek, menyebabkan bau tidak sedap dan dapat menjadi tempat berkembang biak serangga terutama nyamuk, dan menyebabkan terjadinya diare karena lingkungan yang tercemar.

\section{SIMPULAN}

1. Kondisi Kepemilikan Jamban Sehat di Wilayah Kerja Puskesmas Pembina Kota Palembang dengan kategori Sehat sebanyak $32(61,50 \%)$, sementara kategori Tidak Sehat sebanyak $20 \quad(38,50 \%)$. Berdasarkan Hasil uji Statistik menggunakan uji ChiSquare terdapat Hubungan secara parsial dengan nilai $\rho=0,004<0,05$ dengan nilai Odds Ration $=7$,

2. Kondisi Kepemilikan Tempat Pembuangan Sampah di Wilayah Kerja Puskesmas Pembina Kota Palembang dengan kategori sehat sebanyak 6 $(69,20 \%)$, sementara kategori Tidak Sehat sebanyak 16 (30,80\%). Berdasarkan Hasil uji Statistik menggunakan uji Chi-Square terdapat Hubungan secara parsial dengan nilai $\rho=0,000<0,05$ dengan nilai Odds Ration $=13$,

3. Kondisi Saluran Pembuangan Air Limbah di Wilayah Kerja Puskesmas Pembina Kota Palembang dengan kategori sehat sebanyak $35(67,20 \%)$, sementara kategori Tidak Sehat sebanyak 17 (32,70\%). Berdasarkan Hasil uji Statistik menggunakan uji ChiSquare terdapat Hubungan secara parsial dengan nilai $\rho=0,000<0,05$ dengan nilai Odds Ration $=15,7$.

\section{DAFTAR PUSTAKA}

Arikunto, S. (2009). Manajemen Penelitian (10th ed.). PT. Rineka Cipta.

Chandra, B. (2012). Pengantar kesehatan lingkungan. In Jakarta: Penerbit Buku Kedokteran EGC.

Desi Payana. (2009). Hubungan sanitasi lingkungan dengan kejadian penyakit diare pada balita di wilayah kerja Puskesmas 11 Ilir Palembang Skripsi: Abdi Nusa Palembang.

Dinas Kesehatan Kota Palembang. (2017). Data dan Informasi Profil Kesehatan Kota Palembang 2019. Palembang.

Dinas Kesehatan Provinsi Sumatera Selatan. Subdin P2P Sum-Sel. (2019). Data Dasar Kesehatan Kota Palembang Tahun 2019,.

Italia, I., Kamaluddin, H. M. T., \& Sitorus, R. J. (2016). Hubungan Kebiasaan Mencuci Tangan, Kebiasaan Mandi dan Sumber Air Dengan Kejadian Diare pada Balita di Wilayah Kerja Puskesmas 4 Ulu Kecamatan Seberang Ulu I Palembang. Jurnal Kedokteran Dan Kesehatan: Publikasi Ilmiah
Fakultas Kedokteran Universitas Sriwijaya, 3(3), 172-181.

Kementerian Kesehatan RI. (2011). Profil Kesehatan Indonesia RI 2010. In Jakarta: Kementerian Kesehatan Republik Indonesia.

Kementerian Kesehatan RI. (2012). Pedoman Pemberantasan Penyakit Diare. Jakarta: Dirjen PPM dan PL.

Kementerian Kesehatan RI. (2013). Riset Kesehatan Dasar (RISKESDAS) 2013. Laporan Nasional 2013. https://doi.org/10.3406/Arch.1977.1322

Notoatmodjo, S. (2007). No TitleKesehatan Masyarakat, Ilmu dan Seni. Jakarta: PT. Rineka Cipta.

Notoatmodjo, S. (2010). Metodologi Penelitian Kesehatan. Jakarta: PT. Rineka Cipta.

Notoatmodjo, S. (2011). Kesehatan Masyarakat, Ilmu dan Seni. In Jakarta: PT. Rineka Cipta (Revisi, Vol. 413).

Octorina S, F. (2012). Hubungan kondisi lingkungan perumahan dengan kejadian diare di desa Sialang Buah Kecamatan Teluk Mengkudu Kabupaten serdang Bedagai Tahun 2012.

Peraturan Pemerintah RI Nomor 66 Tahun 2014. (n.d.). Peraturan Pemerintah Republik Indonesia. https://doi.org/10.1017/CBO9781107415324.004

Pratama, R. N. (2013). Hubungan antara sanitasi lingkungan dan personal hygiene ibu dengan kejadian diare pada balita di Kelurahan Sumurejo Kecamatan Gunungpati Kota Semarang. Jurnal Kesehatan Masyarakat Universitas Diponegoro, 2(1), 18720.

Riskesdas. (2013). Riset Kesehatan Dasar (RISKESDAS) 2013. Laporan Nasional 2013. https://doi.org/10.3406/Arch.1977.1322

Sarudji, D. (2010). Kesehatan Lingkungan. Karya Putra Darwati, Bandung.

Simatupang, M. M. (2014). Hubungan Sanitasi Jamban dan Air Bersih dengan Kejadian Diare Pada Balita di Kelurahan Terjun Kecamatan Medan Marelan Kota Medan Tahun 2014. Lingkungan Dan Keselamatan Kerja, 3(3), 14517.

Soebagyo, B. (2008). Diare akut pada anak. Surakarta: Universitas Sebelas Maret Press.(Acute Diarrhea in Children).

Supardi Sudibiyo. (2004). Peranan Lingkungan dalam Penularan Penyakit Diare. Jakarta: Berita Pusat Informasi.

UNICEF, W. H. O. (WHO). (2012). Progress On Drinking Water And Sanitation: update. In New York: UNICEF and World Health Organization.

Windusari, Y., \& Sari, N. P. (2015). Kualitas Perairan Sungai Musi Di Kota Palembang Sumatera Selatan. Bioeksperimen: Jurnal Penelitian Biologi, 1(1), 1-5.

World Health Organization (WHO). (2011). Tentang Penyakit Diare dan Penularannya. 